\title{
Effects of high pressure and ohmic heating on shell loosening, thermal and structural properties of shrimp (Pandalus borealis)
}

Dang, Tem Thi; Feyissa, Aberham Hailu; Gringer, Nina; Jessen, Flemming; Olsen, Karsten ; Bøknæs, Niels; Orlien, Vibeke

Published in:

Innovative Food Science and Emerging Technologies

Link to article, DOI:

10.1016/j.ifset.2019.102246

Publication date:

2020

Document Version

Peer reviewed version

Link back to DTU Orbit

Citation (APA):

Dang, T. T., Feyissa, A. H., Gringer, N., Jessen, F., Olsen, K., Bøknæs, N., \& Orlien, V. (2020). Effects of high pressure and ohmic heating on shell loosening, thermal and structural properties of shrimp (Pandalus borealis). Innovative Food Science and Emerging Technologies, 59, [102246]. https://doi.org/10.1016/j.ifset.2019.102246

\section{General rights}

Copyright and moral rights for the publications made accessible in the public portal are retained by the authors and/or other copyright owners and it is a condition of accessing publications that users recognise and abide by the legal requirements associated with these rights.

- Users may download and print one copy of any publication from the public portal for the purpose of private study or research.

- You may not further distribute the material or use it for any profit-making activity or commercial gain

- You may freely distribute the URL identifying the publication in the public portal 
1 Effects of high pressure and ohmic heating on shell loosening, thermal and structural

2 properties of shrimp (Pandalus borealis)

3 Tem Thi Dang ${ }^{\mathrm{a}}$, Aberham Hailu Feyissa ${ }^{\mathrm{b}}$, Nina Gringer ${ }^{\mathrm{b}}$, Flemming Jessen ${ }^{\mathrm{b}}$, Karsten Olsen ${ }^{\mathrm{a}}$, Niels

4 Bøknæs ${ }^{\mathrm{c}}$, Vibeke Orlien ${ }^{\mathrm{a},{ }^{*}}$

5 a Department of Food Science, Faculty of Science, University of Copenhagen, Rolighedsvej 26, 1958

6 Frederiksberg C, Denmark

7 b National Food Institute, Technical University of Denmark, Søltofts Plads, Building 221, DK-2800 Kgs.

8 Lyngby, Denmark

$9 \quad{ }^{\mathrm{c}}$ Royal Greenland A/S, Hellebarden 7, DK-9230 Svenstrup J, Denmark

$10 *$ Corresponding author at: Department of Food Science, Faculty of Science, University of Copenhagen,

11 Rolighedsvej 26, DK-1958 Frederiksberg C, Denmark.

12 E-mail address: vor@food.ku.dk (V. Orlien). 


\section{Abstract}

This study aimed at understanding the effects of high pressure (HP) and ohmic heating (OH) on

15 the peelability, the underlying mechanisms of $\mathrm{HP}$ - and $\mathrm{OH}$-induced shell tightening, the thermal and structural properties of shrimp parts. HP improved the peelability of shrimp at low pressure level $(<350$ $\mathrm{MPa})$ and short holding time ( $\leq 3 \mathrm{~min})$ and the optimum condition for peeling was at $100 \mathrm{MPa}$ for $3 \mathrm{~min}$ at $5^{\circ} \mathrm{C}$. However, a higher pressure level $(>350 \mathrm{MPa})$ led to a decrease in the peelability. High pressure at $600 \mathrm{MPa}$ stabilized cuticular and epidermal collagen and formed new collagen-like structures by new linkages, which strengthened the muscle-shell connection and reduced the peelability. Shrimp meat induced from $\mathrm{HP}$ at $100 \mathrm{MPa}$ and $600 \mathrm{MPa}$ had minorly denatured myofibrillar proteins. $\mathrm{OH}$ as a blanching method did not significantly improve the peelability of shrimp at most of the studied conditions. Some extreme conditions (e.g. at $50^{\circ} \mathrm{C}$ ) caused a markedly low peelability due to occurrence of collagen gelatinization. The gel formation from collagen-gelatin transformation under heating added strength to adherence of shell to epidermis and muscle, as a consequence, a difficult peeling was experienced. $\mathrm{OH}$ also denatured proteins in shrimp meat and caused loss of astaxanthin.

Industrial relevance: The industrial processing of ready-to-eat shrimp involves the on-ice or in-brine maturation process which loosens the shrimp's shell from its meat, and therefore enable the mechanical peeling. However, the traditional maturation is time consuming (up to 4 - 5 days), inevitably leads to reduced quality of shrimp meat. This study shows the possibility of the application of HP at mild pressure levels to promote the shell loosening at short HP processing time ( $\leq 3 \mathrm{~min})$. However, at more severe HP conditions could lead to the shell tightening which was caused by HP-induced stabilization of collagen in shell and epidermis. The study also shows that ohmic heating $(<5 \mathrm{~min})$ might not be a significant blanching method to support the maturation since $\mathrm{OH}$ had minor positive effect on shell loosening at 
35 some $\mathrm{OH}$ conditions (e.g. 2 or $10 \% \mathrm{NaCl}, 92 \mathrm{~V}$, and 30 or $35^{\circ} \mathrm{C}$ ), but had a counter effect at most $\mathrm{OH}$ 36 conditions especially at high temperature.

37 Keywords: shrimp; peeling; shell loosening; ohmic heating; high pressure; collagen 


\section{Introduction}

Peeling is an important step in shrimp processing since the process can affect the yield, sensory, organoleptic and nutritional quality of final shrimp products (Dang et al., 2018a). The tight muscle-shell attachment causes difficulty in peeling freshly caught shrimp. Therefore, shell-loosening is needed to carry out as an essential pre-peeling step before the shrimp can be peeled in an automatic peeler. The most commonly used shell-loosening methods include empirical maturation of shrimp on ice and in brine for up to 4-5 days. However, as shrimp are highly perishable, such a long maturation could cause degradation in quality and risk of microbial growth in final products. A new method is therefore needed to both facilitate the peeling and meanwhile maintain the meat quality. In order to address the issue, our earlier studies (Dang et al., 2018b, 2018c) attempted to apply enzymes and/or ultrasound on shrimp peeling and quality, and found some positive results. Being inclined to green and novel application, more explorations have been continued to other emerging technologies, i.e. high pressure and ohmic heating.

High pressure has increasingly gained interests among food researchers mainly due to its ability to improve food quality and safety (Dang et al., 2018a). Although some attempts have been made to apply high pressure in facilitating deshelling shellfish, e.g. oysters, clams, and mussels, (Bindu, Grinson, Kamalakanth, \& Gopal, 2015; He, Adams, Farkas, \& Morrissey, 2002; Hsu, Hwang, Chi, \& Lai, 2010; Voisin, 2001), less attention has been paid on shrimp peeling. Scarcely, in an American Society of Agricultural and Biological Engineers meeting paper by Yang et al. (2010), HP was tested on peelability, tail integrity, drip loss and color changes of white shrimp (Penaeus vannamei Boone). It was found that $\mathrm{HP}$ at $200 \mathrm{MPa}$ for three minutes improved those tested attributes. Particularly, HP-treated shrimp had the tail being less lost during peeling, drip loss being reduced by half, color remaining unchanged, all compared to untreated shrimp. Pressure appeared to promote water movement into the shrimp and to denature protein that enhanced water holding capacity due to exposure of water binding sites at the 
61 protein surface. However, HP-induced changes in thermal-stable and structural properties of shrimp have 62 not been investigated by far.

Ohmic heating is a thermal method which involves dissipation of electrical energy to heat, due to the electrical resistance of the food (Jaeger et al., 2016). Ohmic heating is used to precook, blanch, cook and sterilize vegetables, fruit, and meat (Allali, Marchal, \& Vorobiev, 2010; Mesias, Wagner, George, \& Morales, 2016; Sengun, Turp, Icier, Kendirci, \& Kor, 2014; Zell, Lyng, Cronin, \& Morgan, 2010). Ohmic heating is found to be efficient in tomato peeling (Wongsa-Ngasri \& Sastry, 2015, 2016a, 2016b). The use of ohmic heating was addressed to a reasonably short time over traditional steaming, an improved diffusion of peeling media through tomato skin, an improved firmness of peeled tomato, and reduction of peeling agent (lye). However, based on our current knowledge, no previous studies have been conducted on shrimp peeling. The potential of ohmic heating on shrimp peeling was assumed and recommended for future investigation in a previous study on effect of ohmic heating on shrimp quality (Pedersen, Feyissa, Kavli, \& Frosch, 2016). In comparison with conventional steam, ohmic heating was found to be more uniform and faster in cooking different parts of shrimp (head, body, and tail), comparable texture and drip loss, and less color difference (Lascorz, ToreIla, Lyng, \& Arroyo, 2016; Pedersen et al., 2016).

Proteins are the major components in shell and meat part of shrimp (Heu, Kim, \& Shahidi, 2003; Rodde, Einbu, \& Varum, 2008). Proteins are the main contributors to the textural and functional properties (e.g. texture, solubility, extractability, viscosity and water holding capacity), which are associated with the quality of shrimp (Herrero, 2008). Therefore, information on protein structure will provide a precise assessment on the textural and functional properties of shrimp. Spectroscopic methods

82 have been used to obtain structural changes occurring during food processing (Herrero, 2008).

83 Fluorescence spectroscopy is, for instance, a rapid and nondestructive technique exhibiting a huge 
potential in food quality assessment based on descriptive and predictive methods (Karoui \& Blecker, 2011). In principle, a fluorescent molecule (fluorophore) absorbs energy of UV/VIS light at a specific wavelength and emits it at higher wavelength (Hassoun \& Karoui, 2017). A excitation-emission matrix (EEM) forms a fluorescence landscape allowing to obtain more information about fluorophores present in the sample (Hassoun \& Karoui, 2017). EEM fluorescence spectroscopy has been used to monitor the freshness of fish over a storage period by tracking changes in fluorescence intensity of certain intrinsic fluorophores (aromatic amino acids, lipids and pigments) of fish (Dufour, Frencia, \& Kane, 2003; ElMasry et al., 2015; ElMasry, Nakazawa, Okazaki, \& Nakauchi, 2016). Changes of fluorescence behavior during treatment (e.g. high pressure, heating) also allowed assessment of toughness of quality attributes such as palatability of beef meat (Swatland, Nielsen, \& Andersen, 1995), and tenderness of beef meat (Egelandsdal, Wold, Sponnich, Neegård, \& Hildrum, 2002). Fluorescence studies on meat and seafood reported in the literature are dominated by fluorophore of collagen, tryptophan, NADH, vitamin A, and fluorescent oxidation products (Hassoun \& Karoui, 2017; Karoui \& Blecker, 2011). Therefore, identifying changes of fluorophore behavior of shrimp during treatments (e.g. high pressure, ohmic heating, steaming, enzyme hydrolysis) may help assess the effect of the treatments on shrimp quality. In addition to fluorescence spectroscopy, Raman spectroscopy is also very useful for studying structural changes that occur during treatment (Herrero, 2008). By monitoring changes in spectral bands, one can obtain information about $\alpha$-helix, $\beta$-sheet structures of protein, consequently predict the quality of food (Herrero, 2008). Raman spectra also give useful information on other biocomponents such as lipids, pigments, polysaccharides, water, calcites etc. (LiChan, 1996).

The objective of this work was to study the effect of high-pressure treatment and ohmic heating on the peelability, the thermal and structural properties of body parts (shell and meat) of cold water shrimp, and to understand the mechanisms associated with peeling. 


\section{Materials and methods}

108

109

110

111

\subsection{Materials}

Cold water shrimp (P. borealis) were provided by Royal Greenland A/S (Svenstrup, Aalborg, Denmark). The shrimp (160 - 200 shrimp/kg in size) were individually frozen, packed in carton packages and stored at $-21^{\circ} \mathrm{C}$. Fine table salt $(\mathrm{NaCl})$ was obtained from a local supermarket (Copenhagen, Denmark). Endocut 03L (Endo3) and Tail21 enzyme preparations were obtained from Tailorzyme A/S (Sørborg, Denmark) and stored at $4-5^{\circ} \mathrm{C}$ until use. Endo3 is a food-grade endoprotease with broad specificity (60 Units/g) produced from Bacillus clausii whereas Tail21 is also a food-grade endoprotease but with high specificity (65 Units $/ \mathrm{mL}$ ) produced from fungi Rhizomucor miehei, as stated by the manufacturer.

\subsection{High pressure}

Frozen shrimp were thawed in tap water $\left(\sim 12^{\circ} \mathrm{C}\right)$ for 20 minutes. Thawed shrimp were packed in a Nalgene HDPE plastic bottle and the bottle was fully filled with chilled distilled water $\left(5^{\circ} \mathrm{C}\right)$ and sealed with a cap. The bottle was placed in a pressure vessel submerged in hydrostatic fluid medium and pressurized in a Food Processing high pressure unit (QFP-6, Avure Technoliges AB, Vesterås, Sweden) between $100-600 \mathrm{MPa}$ for $30 \mathrm{~s}-3 \mathrm{~min}$ at $5-20^{\circ} \mathrm{C}$. These selected ranges of parameters were based on the preliminary experiments in which peelability (by hand) and quality (texture and color by observation) of shrimp pressurized at extended ranges were considered. Immediately after high pressure treatment, shrimp were placed in ice water bath.

Response surface methodology (RSM) based central composite design (CCD) was chosen to evaluate the effect of three processing conditions i.e. pressure (P, $100-600 \mathrm{MPa})$, time (t, $0.5-3 \mathrm{~min})$, and temperature $\left(\mathrm{T}, 5-20^{\circ} \mathrm{C}\right)$ on peeling work. The complete design consisted of 18 -treatment 
combinations including four replicates at central point. Two replicates were conducted for 14 treatments

130 at factorial points. Each treatment was performed on ten shrimp. Data analysis was performed using the

131 software SAS 9.4 (SAS ${ }^{\circledR}$ Institute Inc., Cary, New York). Experimental data were fitted to a second-

132 order polynomial model Eq. (1) and regression coefficients were obtained.

$$
Y=\beta_{0}+\sum_{i=1}^{3} \beta_{i} X_{i}+\sum_{i=1}^{3} \beta_{i i} X_{i}^{2}+\sum_{i=1 j}^{2} \sum_{j=1}^{3} \beta_{i j} X_{i} X_{j}
$$

133 Where $\mathrm{Y}$ represents the response variable (peeling work, $\mathrm{mJ} / \mathrm{g}$ ), $\beta_{0}$ is intercept, $\beta_{\mathrm{i}}, \beta_{\mathrm{ii}}$, and $\beta_{\mathrm{ij}}$ are

134 coefficients of the linear, quadratic and interaction effect, respectively. $X_{i}$ and $X_{j}$ are the independent 135 variables $(\mathrm{P}, \mathrm{T}, \mathrm{t})$.

136

137

138

140

141

142

143

144

145

146

147

148

149

\subsection{Ohmic heating}

A laboratory scale ohmic heater (BCH Ltd., Landcashire, UK) used to blanch shrimp consisted of a voltage regulator $(0-230 \mathrm{~V}, 60 \mathrm{~Hz}, 40 \mathrm{~A})$ suppling power to a rectangular polyethylene heating cell through two titanium electrodes positioned at two ends of the cell. The cell had inner width of $9.5 \mathrm{~cm}$ and inner length of $12 \mathrm{~cm}$ (also distance between the electrodes). Voltage and electric current were recorded by a built-in data logger system, and temperatures were monitored using a K-type thermocouple connected with TC-08 data logger (Pico Technology, Cambridgeshire, UK).

Frozen shrimp $(\sim 120 \mathrm{~g})$ were thawed in tap water bath for 20 min and then were placed into the heating cell. $\mathrm{NaCl}$ solution ( $400 \mathrm{~mL}, 2 \%$ or $10 \% \mathrm{w} / \mathrm{v}$ concentration) was prepared and added to ohmic heating cell and then the shrimp were placed within solution and heated to the desired temperature. The shrimp were heated to different temperature $\left(30,35,40,50\right.$ and $\left.60^{\circ} \mathrm{C}\right)$ and at different voltages $(92,138$ and $184 \mathrm{~V})$. Immediately after treatment, the shrimp were cooled in an ice water bath for 1 min before maturing in $2 \% \mathrm{NaCl}$ for $24 \mathrm{~h}$ at $2{ }^{\circ} \mathrm{C}$. The matured shrimp were washed with ice water and then placed under ice cubes during peeling. 


\subsection{Peelability}

The shrimp peelability was measured using the method reported in our earlier study (Gringer et al.,

152 2018). In the present study, peeling work will represent the peelability of shrimp. Briefly, the three first

153 abdominal segments of shrimp without legs were cut off, weighed $\left(\mathrm{m}_{\mathrm{i}}\right)$ and horizontally hold by a pin 154 attached to a customized fixture. The edge of the C-shaped shell of the three-segment portion was 155 clamped by a clip attached to the texture analyzer (TA, 1000-g cell load, Brookfield AMETEK Inc., 156 Middleboro, Massachusetts, USA) as the probe. The tension test was implemented to vertically pull off

157 the shell from the meat (the peeling process). After the peeling, the shrimp was classified as completely

158 peeled or incompletely peeled, and peeling work was calculated. The completely peeled shrimp was the 159 shrimp having no shells remaining on the meat. The incompletely peeled shrimp having any shells 160 remaining on the meat. The peeling work ( $\mathrm{mJ} / \mathrm{g}$ shrimp) was defined as the work required to pull off the 161 shell from the three abdominal segments. The lower peeling work corresponded to the easier peeling.

162 The peeling work calculation was based on the force-distance curve by multiplying the force by the 163 distance of shell pulling and dividing by the weight of the three segments (Eq.(2)). Only the peeling work 164 obtained from the completely peeled shrimp are presented and evaluated.

$$
\mathrm{W}=\frac{\mathrm{Fd}}{\mathrm{m}_{\mathrm{i}}}
$$

165 Where: $\mathrm{W}(\mathrm{mJ} / \mathrm{g})$ is the work. $\mathrm{F}(\mathrm{N})$ is force applied to peeling. $\mathrm{d}(\mathrm{mm})$ is distance pulling the shell off. $166 \mathrm{~m}_{\mathrm{i}}(\mathrm{g})$ is initial weight of three segments with shell before peeling.

\subsection{Differential scanning colorimetry (DSC)}

Two HP treatments: $100 \mathrm{MPa}$ for $1.75 \mathrm{~min}$ at $12.5^{\circ} \mathrm{C}(\mathrm{HP} 100)$ and $600 \mathrm{MPa}$ for $1.75 \mathrm{~min}$ at $12.5^{\circ} \mathrm{C}$ (HP600) and two $\mathrm{OH}$ treatments: $10 \% \mathrm{NaCl}, 138 \mathrm{~V}$, and $30^{\circ} \mathrm{C}(\mathrm{OH} 30)$ and $10 \% \mathrm{NaCl}, 138 \mathrm{~V}$, and $50^{\circ} \mathrm{C}$

170 (OH50) were selected to evaluate the thermal and structural properties. HP100 and OH30 represented 
171 rather good peeling treatments in high pressure and ohmic heating, respectively, whereas HP600 and

$172 \mathrm{OH} 50$ represented rather bad peeling treatments in high pressure and ohmic heating, respectively.

173 DSC measurements were carried out with Mettler Toledo DSC I calorimeter, which is based on the

174 heat flux principle. Calibration of heat flow and temperature was done with indium $\left(\mathrm{T}_{\mathrm{m}}=156.6^{\circ} \mathrm{C}, \Delta \mathrm{H}_{\text {fus }}\right.$

$175=28.5 \mathrm{~J} / \mathrm{g})$ and zinc $\left(\mathrm{T}_{\mathrm{m}}=419.5^{\circ} \mathrm{C}, \Delta \mathrm{H}_{\text {fus }}=107.5 \mathrm{~J} / \mathrm{g}\right)$ as standards. A sample of $\sim 10 \mathrm{mg}$ was placed in

176 Mettler Toledo 40- $\mu \mathrm{L}$ standard aluminum crucible with pin and sealed with a lid. Measurements were

177 made at $10^{\circ} \mathrm{C} / \mathrm{min}$ scan rate in the temperature range $20-80^{\circ} \mathrm{C}$. Two to four replicates per treatment were

178 performed depending the availability of sample, and the results were presented as the average of the

179 replicates. DSC thermogram analysis was carried out using STARe software (Mettler Toledo).

180 2.6. Spectroscopy

181 For better understanding of structural behaviors of shrimp parts (shell and meat) subjected to two 182 main technologies: $\mathrm{HP}$ and $\mathrm{OH}$, several other shrimp subjected to other techniques such as steam, 183 Endocut 03L protease (Endo3), Tail21 protease (Tail21), and sodium chloride were added to

184 spectroscopic measurements. Steam is a traditional thermal process and thus was selected to monitor the 185 thermal effect in HP (if any) and $\mathrm{OH}$. Shrimp were steamed for $90 \mathrm{~s}$ (shrimp temperature $90^{\circ} \mathrm{C}$ ). Endo3 186 and Tail21 have been the most and least, respectively, effective enzymes in shrimp shell-loosening in 187 our earlier study (Dang et al., 2018b), and were selected to evaluate the shell-loosening aspect and 188 structural changes associated with shell-loosening. Shrimp were submerged in an enzyme solution ( $2 \%$ $189 \mathrm{NaCl}, 0.5 \%$ enzyme, and water) for $20 \mathrm{~h}$ at $5^{\circ} \mathrm{C}$ with continuous agitation. Sodium chloride $(\mathrm{NaCl})$ was 190 selected to evaluate ionic effect as well as mimic a commonly used maturation method in shrimp industry. 191 Shrimp were submerged in $2 \% \mathrm{NaCl}$ solution for $24 \mathrm{~h}$ at $5^{\circ} \mathrm{C}$ with continuous agitation. 


\subsubsection{Fluorescence spectroscopy}

193 Fluorescence spectroscopic measurements were taken from the surface of shrimp parts (shell and 194 meat) using a Cary Eclipse fluorescence spectrophotometer (Varian Inc., Palo Alto, California, US) 195 through a double arm optical fiber probe bundle (C Technologies, Cedar Knolls, NJ). The probe was set 196 at 45-degree angle and the sample end of the probe was kept at 5-mm distance from the sample.

197 Excitation spectra were recorded in the $270-380 \mathrm{~nm}$ range with a 10-nm interval, and emission spectra 198 were recorded in the $270-520 \mathrm{~nm}$ range with a $2-\mathrm{nm}$ interval. The excitation and emission ranges were 199 chosen based on preliminary survey scans. Both slit widths were set to $5 \mathrm{~nm}$, and the scanning speed was $20012,000 \mathrm{~nm} / \mathrm{min}$. Intensity data were plotted in an excitation emission matrix (EEM). Four to seven 201 measurements were performed on two to four shrimp for each treatment.

\subsubsection{Raman spectroscopy}

A Bruker RAM II Raman Spectrometer (Karlsruhe, Germany) was used to obtain the Raman 204 spectra, which were acquired and processed with the Opus software (Bruker, Karlsruhe, Germany).

Ground freeze-dried sample was placed on a stainless steel cup, and then laser light with power of 400 $\mathrm{mW}$ was focused on the solid sample. Each spectrum was collected at room temperature under the following condition: $8 \mathrm{~cm}^{-1}$ resolution, 5-min scan time ( 365 scans), over $3500-100 \mathrm{~cm}^{-1}$. The Raman spectra of each sample were obtained in triplicate and the results were recorded as the average of the triplicate.

\subsection{Data analysis}

One way and multiway ANOVAs and RSM analysis were performed using SAS statistical software

212 (version 9.4, SAS ${ }^{\circledR}$ Institute Inc., Cary, NY). Mean comparison among treatments was performed by 213 Student-Newman-Keuls test. 


\section{3. Results and discussion}

\section{3.1. High pressure on peelability}

216 Pressure level is an essential parameter in any HP experiments. Its individual effect on shrimp 217 peeling work when time and temperature are fixed at $1.75 \mathrm{~min}$ and $12.5^{\circ} \mathrm{C}$ is presented in Figure 1A. As 218 seen, low pressure level $(<350 \mathrm{MPa})$ offered a lower peeling work than that of control shrimp. However, 219 its interactions with time and temperature in a HP system are of importance to optimize a processing 220 condition.

The peeling work of shrimp pressurized at various conditions was measured. The RSM results obtained from various high pressure treatments were fitted to Eq. (1) and a complete second-order polynomial regression model Eq. (3) was obtained. The ANOVA and lack of fit test showed that the total model was significant $(p<0.05)$ for fitting the response, and adequately represented the real relationship between tested parameters and response $(p$ lack-of-fit $>0.05)$. The determination coefficient $\left(\mathrm{R}^{2}\right)$ of the model was 0.51 , which referred $51 \%$ of variations that could be explained by the fitted model (Figure

1B). The linear and interaction effects were more significant than quadratic effects. Interaction between pressure and time was the most significant term $(p=0.047)$ in the model. Amongst the three factors studied, pressure had the most significant overall effect $(p=0.019)$ (i.e. sum of linear, quadratic, pressure-time interaction and pressure-temperature interaction effects of pressure factor), followed by pressurization time $(p=0.052)$ (i.e. sum of linear, quadratic, time-pressure interaction and timetemperature interaction effects of time factor), and finally least important temperature $(p=0.676)$ (i.e. sum of linear, quadratic, temperature-pressure interaction and temperature-time interaction effects of temperature factor).

W

$$
\begin{aligned}
& \left.=11.11-0.011 \mathrm{P}-0.895 \mathrm{t}-0.06 \mathrm{~T}+0.004 \mathrm{Pt}+7.6 * 10^{-5} \mathrm{PT}+0.088 \mathrm{Tt}+9 * 10^{-6} \mathrm{P}^{2}-\mathrm{C}^{(3}\right) \\
& \mathrm{T}^{2}
\end{aligned}
$$


235 Where: $\mathrm{P}$ is pressure $(\mathrm{MPa}), \mathrm{t}$ is time $(\mathrm{min})$, and $\mathrm{T}$ is temperature $\left({ }^{\circ} \mathrm{C}\right)$.

236 The contour response surface plots varying two independent factors when the third factor kept 237 constant at its middle level are shown in Figure 1C-D. Increasing pressure or time resulted in increases 238 in the peeling work, whereas temperature appeared to have less significant effect on peeling work. The 239 peeling work decreased with decreases of pressure and time, reaching lowest peeling work (two lines 8 240 in contour plot Figure 1C) at either a pressure of $100-200 \mathrm{MPa}$ and time $2.5-3 \mathrm{~min}$ or $250-600 \mathrm{MPa}$ and $0.5 \mathrm{~min}$ at fixed temperature of $12.5^{\circ} \mathrm{C}$. When pressurization for $1.75 \mathrm{~min}$ at any temperature $(5-$ $24220^{\circ} \mathrm{C}$ ), pressures from $100-350 \mathrm{MPa}$ had similar effect to one another on peeling work, but increasing pressure at range $350-600 \mathrm{MPa}$ resulted in increases in peeling work (Figure 1D).

The calculation of lowest predicted peeling work was performed based on Eq. (3) in order to establish the optimum HP condition for peeling. The criteria for calculation included pressure range from 100 to $600 \mathrm{MPa}$ with $10-\mathrm{MPa}$ interval, time range from 0.5 to 3 min with 0.1 -min interval, and temperature range from 5 to $20^{\circ} \mathrm{C}$ with an interval of $1^{\circ} \mathrm{C}$. The result showed that the optimum condition to obtain the lowest peeling work $(6.6 \mathrm{~mJ} / \mathrm{g})$ was positioned at $100 \mathrm{MPa}, 3 \mathrm{~min}$ and $5^{\circ} \mathrm{C}$. This peeling work was $2.1 \mathrm{~mJ} / \mathrm{g}$ lower than that of the control shrimp. However, the optimum condition was not validated by experiment, since it is out of scope of this study.

\subsection{Ohmic heating on peelability}

Effect of ohmic-heating blanching (OH blanching) on shrimp peeling work is shown in Table 1.

253 Generally, $\mathrm{OH}$ blanching at most of studied conditions did not improve the peelability of subsequent salt 254 matured shrimp. Comparing means of all samples showed that all OH-treated shrimp had similar or 255 significantly higher peeling work than control shrimp (unblanched and matured in $2 \% \mathrm{NaCl}$ for $24 \mathrm{~h}$ ). 
Three-way ANOVA showed that all the three $\mathrm{OH}$ parameters, i.e. salt concentration, voltage and 257 temperature significantly influenced the peeling work. Interactions between salt and voltage and between 258 salt and temperature were significant whereas interaction between voltage and temperature was not significant. Increasing voltage and temperature resulted in increases in the peeling working, probably 260

\subsection{Shell and meat characteristics}

\subsubsection{Thermal properties by differential scanning calorimetry (DSC)}

DSC analysis was performed to understand thermal properties of shrimp parts after high pressure and ohmic heating treatments. Figure 2 shows the DSC thermograms of parts of shrimp after high pressure and ohmic heating treatments. For epidermis, the endothermic peak at $\sim 55^{\circ} \mathrm{C}$ was seen in raw, $\mathrm{HP} 100, \mathrm{HP} 600$ and $\mathrm{OH} 30$ samples but disappeared in $\mathrm{OH} 50$. Two additional peaks at $\sim 58^{\circ} \mathrm{C}$ and $69^{\circ} \mathrm{C}$ were seen in HP100 epidermis, and a small peak at $\sim 65^{\circ} \mathrm{C}$ newly appeared in $\mathrm{OH} 30$. No peaks were observed in the $\mathrm{OH} 50$ thermogram, indicating that $\mathrm{OH} 50$ denatured all proteins in epidermis. The transition peak at $55^{\circ} \mathrm{C}$ was identified as sarcoplasmic and connective (collagen) proteins based on previous studies in shrimp (Schubring, 2009; Sriket, Benjakul, Visessanguan, \& Kijroongrojana, 2007; Verhaeghe et al., 2016). The $55^{\circ} \mathrm{C}$ peak in raw epidermis shifted towards $56^{\circ} \mathrm{C}$ in $\mathrm{OH} 30$ epidermis and $57^{\circ} \mathrm{C}$ in HP600. Additionally, enthalpy of transition increased from $0.07 \mathrm{~J} / \mathrm{g}$ in raw epidermis to $0.19 \mathrm{~J} / \mathrm{g}$ in $\mathrm{OH} 30$ and to $0.63 \mathrm{~J} / \mathrm{g}$ in HP600 epidermis. The change in the endothermic peak temperature and the increased transition enthalpy suggest that OH30 and HP600 stabilized the structure of sarcoplasmic and connective proteins at different extent (Potekhin, Senin, Abdurakhmanov, \& Tiktopulo, 2009). The existence of new peaks in the thermogram after high pressure treatment was also previously observed in pressurized fish muscle, which were attributed to the formation of structures that were stabilized by 
279 hydrogen bonds (Angsupanich, Edde, \& Ledward, 1999; Angsupanich \& Ledward, 1998; Schubring, 280 2005). When pressure level increased from $100 \mathrm{MPa}$ to $600 \mathrm{MPa}$, the two peaks of 281 sarcoplasmic/connective proteins merged to become a broader peak. This indicates that increasing 282 pressure, at least to $600 \mathrm{MPa}$, led to an accelerated formation of new structures that were similar to native 283 sarcoplasmic/connective proteins and an increased stabilization of native sarcoplasmic/connective 284 proteins.

For shell, DSC thermograms displayed one large endothermic peak at $44-45^{\circ} \mathrm{C}$ in raw and all 286 treated shells. The peak was assigned to the helix-coil transition temperature of collagen as the most abundant protein (60-75\%) in total proteins of shrimp shell (Ong, Danujatmiko, Aylianawati, \& Sudaryanto, 2014) and also the major structural protein found in skin and bone of all animals (Wasswa, 289 Tang, \& Gu, 2007). The transition temperature slightly decreased with increasing high pressure by a maximum of $0.8^{\circ} \mathrm{C}$ at the highest pressure level (600 MPa) compared to raw shell. However, the enthalpy change $(\Delta \mathrm{H})$ and half-width temperature increased with increasing pressure, indicating pressure-induced stabilization of collagen structure. This pressure-induced stabilization was observed in pig acid-soluble collagen (Chen, Ma, Zhou, Liu, \& Zhang, 2014; Potekhin et al., 2009) and bullfrog skin collagen (Nan et al., 2018). Some interpretations could be addressed to this phenomenon. Chen et al. (2014) suggested that high pressure at $500 \mathrm{MPa}$ was speculated to form new hydrogen bonds between collagen and water and promoted the aggregation of collagen. Nan et al. (2018) attributed the stabilization to the dominance of axial pressure (pressure perpendicular to collagen axis) which compressed and strengthened the triplehelix structure of collagen. The thermal stability of collagen could also be related to the state of intermolecular crosslinks that are of importance in stabilization and continuity of molecules of collagen 300 (Kopp, Bonnet, \& Renou, 1990). Accordingly, high pressure might introduce new crosslinks or promote stronger existing crosslinks, in effect stabilizing the collagen structure. 
than in the raw shell. This indicates that $\mathrm{OH}$ readily denatured cuticular collagen even at low temperature

$30^{\circ} \mathrm{C}$ to lesser extent and accelerating extent at $50^{\circ} \mathrm{C}$. Due to a short holding time $(\sim 10 \mathrm{~s})$ at $50^{\circ} \mathrm{C}$ in $\mathrm{OH}$,

the $\mathrm{OH}$-induced denaturation of collagen was partial. Partial denaturation of collagen by $\mathrm{OH}$ could be

the reason of increasing peeling work (Table 1) that challenged the shrimp peeling. When collagen is

heated, intramolecular hydrogen bond breakage results in shrinkage of the collagen fibers, followed by

solubilization and gelatinization (Kopp et al., 1990). The collagen gelatinization formed a gel that was

able to glue the shell to the epidermis and the meat, consequently separation of the shell from meat was difficult.

For muscle, a visible peak at $\sim 39^{\circ} \mathrm{C}$ was present in raw muscle and other treated muscles, except

312 for muscle treated with OH50. This peak was assigned to the denaturation temperature of myosin 313 (Schubring, 2009). This temperature was higher than the $37.1^{\circ} \mathrm{C}$ reported by Schubring (2009) for the same shrimp species. The myosin peak slightly decreased with increasing pressure both in enthalpy and temperature values, indicating partial denaturation caused by high pressure. High pressure was also found to denature myosin of ocean perch, saithe, herring fish muscle (Schubring, 2005). Like high pressure,

$\mathrm{OH} 30$ destabilized the structure of myosin, evidenced by decline in both enthalpy and temperature values of the myosin peak. OH50 completely denatured myosin and the peak disappeared. This finding is in agreement with the result from Schubring (2009) that the peak disappeared after preheating the shrimp muscle at $45^{\circ} \mathrm{C}$. The DSC equipment used was not able to detect actin peak, yet actin was found to be more resistant to heat than myosin (Schubring, 2005).

\subsubsection{Raman spectra of shrimp}

The main composition of shrimp meat (P. borealis) comprises of protein ( $84 \%$, dry matter basis), 
$40 \%$ protein (dry matter basis), $17-20 \%$ chitin (dry matter basis), and 34\% ash (mainly calcium carbonate, dry matter basis) (Rødde, Einbu, \& Vårum, 2008). Chitin is a modified polysaccharide that contains nitrogen in their polymerized $\mathrm{N}$-acetylglucosamine structure (Raabe et al., 2006). Vibrational spectra of chitin and protein share many common peaks, especially amide groups. Characterization of the distinct peaks of chitin has previously been attempted by purification and fractionation (Hejazi, Behzad, Heidarian, \& Nasri-Nasrabadi, 2018; Rahman \& Halfar, 2014), but the results were not in agreement. Hejazi et al. (2018) reported that the peak at $\sim 1540 \mathrm{~cm}^{-1}$ was one of indicative peaks for a complete protein removal, whereas Rahman and Halfar (2014) reported that peaks distinguished from the presence of collagen position in the fingerprint polysaccharide regions $<900 \mathrm{~cm}^{-1}$. The inconsistence in the findings can arise from the difficulty of complete separation of chitin from collagen in a mineralized chitin-collagen matrix (Raabe et al., 2006). Under taxonomic point of view, lobster and shrimp belong to the crustacean group, therefore discussion concerning a mineralized chitin-collagen matrix of shrimp will refer to a mineralized chitin-collagen matrix of lobster reported by Raabe et al. (2006). In this context, the chitin nanofibril is coated by collagen fibrils, thus it is assumed that collagen will be more susceptible to treatments and that collagen will be addressed in discussion when analyzing spectra of shrimp shells.

FT-Raman spectra of shrimp meat and shell subjected to high pressure, ohmic heating, steam, enzyme, and salt are presented in Figure 3. In general, structures of elements in meat were less susceptible to the treatments than structures in shell. As for meat, the band from 1625 to $1700 \mathrm{~cm}^{-1}$ was assigned to amide $\mathrm{I}$, which is mainly due to $\mathrm{C}=\mathrm{O}$ stretching and minor contribution from $\mathrm{N}-\mathrm{H}$ in-plane bending (LiChan, 1996). The amide I band is useful for the investigation of secondary structure (LiChan, 1996). The amide I peak was positioned at $1658 \mathrm{~cm}^{-1}$ for raw meat and all treatments except for OH50 
348 The shifting and broadening during heating were indicators of the gradual loss of $\alpha$-helix structure and 349 increased formation of $\beta$-sheet and random coil (David, Foley, Mavon, \& Enescu, 2008; Ngarize, 350 Herman, Adams, \& Howell, 2004), which was associated with heat denaturation. Thus, OH50 and steam 351 denatured the meat proteins to some extent. OH50-treated meat reduced the peak intensity at $1518 \mathrm{~cm}^{-1}$, 352 which, together with the peaks at 1156 and $1006 \mathrm{~cm}^{-1}$, are characteristics of carotenoids (mostly 353 astaxanthin in shrimp) (Rau et al., 2017). This finding suggests that loss of some astaxanthin pigments 354 in shrimp meat could occur either during ohmic heating at $50^{\circ} \mathrm{C}$ or during peeling. It is noteworthy that 355 OH50-treated shrimp had a higher peeling work compared to the non-OH treated control shrimp $(9.8$ $356 \mathrm{~mJ} / \mathrm{g}$ vs $4.2 \mathrm{~mJ} / \mathrm{g}$, respectively) and being difficult to peel, thus attempts to pull the shell off probably 357 removed some surface pigments on shrimp meat. Interestingly, the overall spectrum of Endo3-treated 358 359

As seen from Figure 3, more peaks in the Raman spectra of the shell were affected by the meat was similar to that of raw meat, suggesting that the most shell-loosening effective enzyme did not affect the meat quality of shrimp.

treatments. Heat denaturation of protein (mainly collagen) happened to steam and OH50 shells, evidenced by the shifting and broadening of the amide I peak $\left(1658 \mathrm{~cm}^{-1}\right)$. The characteristic peaks of carotenoids $\left(1518,1158\right.$, and $\left.1004 \mathrm{~cm}^{-1}\right)$ in shells treated with OH50 and Tail21 increased in intensity compared to other samples, indicating an increase of carotenoids in OH50- and Tail21-treated shell. The increased pigments in OH50 shell were likely transferred from the meat. As mentioned above, OH50treated meat lost a certain amount of carotenoids. The pigment transfer was indeed due to the difficult peeling of OH50-treated shrimp. The attempts to pull off the shell from the meat of an insufficiently shell-loosened shrimp resulted in the pulling off some meat that were attached tightly to the shell. Pigments adhered in the pulled meat were therefore lost in the remaining meat (Raman spectra obtained) but appeared in the shell (Raman spectra obtained). The increased pigments in Tail21 shell were 
371 enzymatically liberated from protein-pigment binding. The peaks at 1374 and $1079 \mathrm{~cm}^{-1}$ disappeared in 372 OH50 shell, indicating $\mathrm{CaCO}_{3}$ decreased by ohmic heating $50^{\circ} \mathrm{C}$ (Chen, Yang, Zhong, \& Yan, 2017). 373 The peak at $760 \mathrm{~cm}^{-1}$ was found to be diminished in samples containing $\mathrm{NaCl}$ in their maturation solution, 374 i.e. $\mathrm{NaCl}$, Endo3 and Tail21, and this peak was assigned to tryptophan (Nonaka, Lichan, \& Nakai, 1993). 375 The peak $1448 \mathrm{~cm}^{-1}$ contributed by $\mathrm{CH}_{2}-\mathrm{CH}_{3}$ bending in protein (Alimova et al., 2009) was slightly more 376 intense in OH50 and HP600 samples. This peak was insensitive to changes in protein secondary structure 377 but sensitive to the concentrations of $\mathrm{CH}_{2}$ and $\mathrm{CH}_{3}$ groups. The change of this peak was likely caused by 378 the formation of new components in the biological system (Alimova et al., 2009).

\subsubsection{Fluorescence spectra of shrimp}

The excitation-emission fluorescence landscapes of shrimp meat and shell are presented in Figure

4. Three dominant peaks $300 / 350 \mathrm{~nm}\left(\lambda_{\mathrm{Ex}_{\max }} / \lambda_{\mathrm{Em} \max }\right), 330 / 410 \mathrm{~nm}$ and $330 / 490 \mathrm{~nm}$ were present in both meat and shell and were assigned to tryptophan (the first peak) and collagen (the second and third peaks) (Andersen \& Wold, 2003; ElMasry et al., 2016). The signal of tryptophan was stronger in raw meat than raw shell, whereas the signal of collagen was weaker in raw meat than in raw shell. This result suggests that shrimp meat consisted of more tryptophan and less collagen than shell does. The signal of tryptophan became stronger when meat were treated with high pressure 100 and $600 \mathrm{MPa}$, ohmic heating $50^{\circ} \mathrm{C}$, steam, enzymes Endo3 and Tail21, and $\mathrm{NaCl}$, and when shell treated with all studied treatments. In meat, 388 tryptophan fluorescence appeared to be highly dependent on temperature and pressure since the intensity was markedly high in high-level pressure and high-level temperature samples (i.e. HP600, OH50, and steam). Moreover, the maximum emission of tryptophan fluorescence shifted from $340 \mathrm{~nm}$ in native meat to $346 \mathrm{~nm}$ in the meat treated with the three treatments. This shifting (also known as red shift) indicates that the exposure degree of tryptophan residues to the surrounding environment increased and the conformation of protein changed (Vivian \& Callis, 2001). Tryptophan residue is essentially buried in the 
394 interior of the protein by other residues (also called quencher) (Vivian \& Callis, 2001). The use of high 395 temperature or pressure partially or completely unfolded protein and granted water accessibility to 396 tryptophan. Indeed, the Raman spectra provided another evidence of this temperature/pressure 397 denaturation of protein by the shifting and broadening of the amide I band as discussed above. Unlike 398 heating, steaming and high pressure, although fluorescence of Endo3-, Tail21- and $\mathrm{NaCl}$ meat increased 399 compared to raw meat, there was no red shift of emission wavelength. Therefore, the interpretation for 400 the intensity increase might be related to the modification of surface hydrophobicity of protein caused 401 by ionic effect from salt. It is noteworthy that Endo3 and Tail 21 solution each contained $2 \% \mathrm{NaCl}$, equal 402 to concentration of $\mathrm{NaCl}$ sample. Jiang et al. (2015) reported that ionic effects from salt loosened the 403 protein structure and resulted in the modification of surface amino acid distribution, i.e. more fluorescent 404 amino acid residues exposed on the surface of protein.

Peaks at $330 / 390 \mathrm{~nm}, 330 / 410 \mathrm{~nm}$ and $330 / 490 \mathrm{~nm}$ excitation/emission wavelengths were assigned 406

412 predominance of collagen, some authors linked it to energy transfer or absorbance of other compounds.

413 In the angle of energy transfer, pressure resulted in hindrance of energy transfer from red pigments 414 (predominantly astaxanthin) to collagen molecule (Foguel, Chaloub, Silva, Crofts, \& Weber, 1992). In 415 the angle of absorbance of other compounds, Andersen and Wold (2003) discussed that because these 416 red pigments absorbed light strongly in the region $350-520 \mathrm{~nm}$, re-absorbance of collagen fluorescence 
417 might occur, thus fluorescence intensity of collagen was weaker in pigmented materials than non418 pigmented materials. In both explanations, pigments were associated with the intensity of collagen 419 fluorescence. In contrast, in the present study, the pigments were not found to affect the collagen 420 fluorescence. For instance, high pressure increased the fluorescence intensity of shell (fluorescence 421 examined), but the pigments were almost unchanged (Raman examined). Therefore, the increased 422 fluorescence of high-pressure-induced shell may not relate to the pigments. In this context, 423 conformational changes of collagen structure might be the cause of changes in its fluorescence intensity.

Shells treated with proteolytic enzymes (Endo3 and Tail21) both had collagen intensity increased as compared to raw shell. This increase was in good agreement with previous studies (Deyl, Sulcova, Praus, \& Goldman, 1970; Fujimori, 1989), where enzymatic liberation of fluorescent amino acids or crosslinks was attributed to the phenomenon.

\subsubsection{Mechanism of shell tightening}

For high pressure, secondary structure of collagen in HP-treated shells, irrespective of pressure level, was not modified, which was evidenced by the unchanged amide I peak as compared to raw shell in Raman spectra. While the secondary structure was intact, the triple-helix structure of collagen was stabilized by high pressure $(100-600 \mathrm{MPa})$, evidenced by increased helix-coil transition enthalpy. This stabilization could be explained by HP-shortened intramolecular and intermolecular hydrogen bonds and strengthened natural intermolecular crosslinks (HP100) or formation of new crosslinks (HP600). The new crosslinks or stabilized crosslinks emitted much stronger fluorescence in HP shells compared to raw shell. The difficulty in peeling shrimp at high pressure level therefore could be explained by interactions or crosslinks either strengthen the existing bonds or form new bonds, in both cases, could interact or link with materials in epidermis or meat, and consequently peelability was low (Figure 5). 
For ohmic heating, secondary structure of collagen in OH50-treated shell was modified in which some $\alpha$-helices are lost, evidenced by the blue shift of amide I peak, meaning that partial denaturation took place. The partial denaturation was also confirmed by DSC curve, in which transition temperature

442 and enthalpy of collagen decreased as compared to raw shell. In excess water medium, partial 443 denaturation of collagen also means partial gelatinization of collagen to gelatin. This gelatinization could contribute to the difficulty of peeling for shrimp preheated at high temperature (Figure 5). Although collagen structure has been unfolded to some extent, the fluorescence intensity of collagen was still stronger than raw shell. This suggests that the fluorescence intensity was sensitive to partial denaturation.

447 A possible explanation for strong fluorescence of $\mathrm{OH}$ shell was that the partial denaturation exposed 448 some hydrophobic bonds and crosslinks in the core of collagen to the surface, facilitating access to laser light.

\section{Conclusion}

Effects of high pressure and ohmic heating on peelability, thermal and structural properties of shrimp parts (shell and meat) were studied. For high pressure, mild HP conditions (pressure $<350$ MP, holding time $\leq 3 \mathrm{~min}$ ) reduced the peeling work compared to raw shrimp, but increasing pressure and time led to an increase in the peeling work. Based on a RSM prediction model, an optimum condition of best peeling was obtained, i.e. $100 \mathrm{MPa}$ for $3 \mathrm{~min}$ at $5^{\circ} \mathrm{C}$, under which a peeling work of $6.6 \mathrm{~mJ} / \mathrm{g}$ was needed to peel the shrimp. DSC thermogram and spectroscopic spectra showed that pressurizations at both 100 and $600 \mathrm{MPa}$ minorly denatured myofibrillar proteins (myosin and actin) in meat, and HP600 obviously stabilized connective proteins (collagen) in epidermis and shell. The pressure-induced stabilization of collagen structure could be resulted from shortening existing hydrogen bonds and forming new hydrogen bonds in the triple-helix structure and/or stabilizing intermolecular crosslinks between collagen molecules. This resulted in a high peeling work of shrimp treated with high pressure level. 
462 Ohmic heating as a blanching method did not improve the peelability of shrimp, and at some extreme 463 conditions (high temperature, voltage, salt concentration) the peeling work was much higher than the 464 control. Collagen gelatinization was responsible for this difficult peeling. When shrimp was ohmic heated 465 at a temperature higher than the shell collagen transition temperature $\left(45^{\circ} \mathrm{C}\right)$, the triple-helix structure of 466 collagen molecule started to unfold into random coils that were able to reassemble into a gel matrix at 467 cooling condition. The gel glued the muscle-shell connection even stronger than the native connection. 468 Ohmic heating also denatured proteins in shrimp meat and caused loss of astaxanthin.

\section{Acknowledgements}

470 The authors are grateful to the Green Development and Demonstration Program (GUDP Denmark),

471 The Danish Agrifish Agency, the Ministry of Food, Agriculture and Fisheries for the financial support 472 to the project "Sustainable technologies for the optimization of shrimp production - TECHSHELL" 473 (Grant number 4009-14-0870, 2015).

\section{Conflict of interest}

475 Declarations of interest: none. 
Alimova, A., Chakraverty, R., Muthukattil, R., Elder, S., Katz, A., Sriramoju, V., Lipper, S., \& Alfano, R. R. (2009). In Vivo Molecular Evaluation of Guinea Pig Skin Incisions Healing after Surgical Suture and Laser Tissue Welding Using Raman Spectroscopy. Journal of photochemistry and photobiology. B, Biology, 96(3), 178-183.

Allali, H., Marchal, L., \& Vorobiev, E. (2010). Blanching of Strawberries by Ohmic Heating: Effects on the Kinetics of Mass Transfer During Osmotic Dehydration. Food and Bioprocess Technology, $3(3), 406-414$.

Andersen, C. M., \& Wold, J. P. (2003). Fluorescence of Muscle and Connective Tissue from Cod and Salmon. Journal of Agricultural and Food Chemistry, 51(2), 470-476.

Angsupanich, K., Edde, M., \& Ledward, D. A. (1999). Effects of High Pressure on the Myofibrillar Proteins of Cod and Turkey Muscle. Journal of Agricultural and Food Chemistry, 47(1), 92-99. Angsupanich, K., \& Ledward, D. A. (1998). High Pressure Treatment Effects on Cod (Gadus Morhua) Muscle. Food Chemistry, 63(1), 39-50.

Bindu, J., Grinson, J., Kamalakanth, C. K., \& Gopal, T. K. S. (2015). High Pressure Treatment of Green Mussel Perna Viridis Linnaeus, 1758: Effect on Shucking and Quality Changes in Meat During Chill Storage. Indian Journal of Fisheries, 62(2), 70-76.

Chen, L. Q., Ma, L., Zhou, M. R., Liu, Y., \& Zhang, Y. H. (2014). Effects of Pressure on Gelatinization of Collagen and Properties of Extracted Gelatins. Food Hydrocolloids, 36, 316-322.

Chen, X., Yang, H., Zhong, Z., \& Yan, N. (2017). Base-Catalysed, One-Step Mechanochemical Conversion of Chitin and Shrimp Shells into Low Molecular Weight Chitosan. Green Chemistry, 19(12), 2783-2792. 
498 Dang, T. T., Gringer, N., Jessen, F., Olsen, K., Bøknæs, N., Nielsen, P. L., \& Orlien, V. (2018a). 499 Emerging and Potential Technologies for Facilitating Shrimp Peeling: A Review. Innovative $500 \quad$ Food Science \& Emerging Technologies, 45, 228-240.

501 Dang, T. T., Gringer, N., Jessen, F., Olsen, K., Bøknæs, N., Nielsen, P. L., \& Orlien, V. (2018b). Enzyme502 Assisted Peeling of Cold Water Shrimps (Pandalus Borealis). Innovative Food Science \& Emerging Technologies, 47, 127-135.

Dang, T. T., Gringer, N., Jessen, F., Olsen, K., Bøknæs, N., Nielsen, P. L., \& Orlien, V. (2018c). Facilitating Shrimp (Pandalus Borealis) Peeling by Power Ultrasound and Proteolytic Enzyme. Innovative Food Science \& Emerging Technologies, 47, 525-534.

David, C., Foley, S., Mavon, C., \& Enescu, M. (2008). Reductive Unfolding of Serum Albumins Uncovered by Raman Spectroscopy. Biopolymers, 89(7), 623-634.

Deyl, Z., Sulcova, H., Praus, R., \& Goldman, J. N. (1970). A Fluorescent Compound in Collagen and Its Relation to Age of Animal. Experimental Gerontology, 5(1), 57-\&.

Dufour, É., Frencia, J. P., \& Kane, E. (2003). Development of a Rapid Method Based on Front-Face Fluorescence Spectroscopy for the Monitoring of Fish Freshness. Food Research International, $36(5), 415-423$.

Egelandsdal, B., Wold, J. P., Sponnich, A., Neegård, S., \& Hildrum, K. I. (2002). On Attempts to Measure the Tenderness of Longissimus Dorsi Muscles Using Fluorescence Emission Spectra. Meat Science, 60(2), 187-202.

ElMasry, G., Nagai, H., Moria, K., Nakazawa, N., Tsuta, M., Sugiyama, J., Okazaki, E., \& Nakauchi, S. (2015). Freshness Estimation of Intact Frozen Fish Using Fluorescence Spectroscopy and Chemometrics of Excitation-Emission Matrix. Talanta, 143, 145-156. 
ElMasry, G., Nakazawa, N., Okazaki, E., \& Nakauchi, S. (2016). Non-Invasive Sensing of Freshness Indices of Frozen Fish and Fillets Using Pretreated Excitation-Emission Matrices. Sensors and Actuators B: Chemical, 228, 237-250.

Foguel, D., Chaloub, R. M., Silva, J. L., Crofts, A. R., \& Weber, G. (1992). Pressure and Low Temperature Effects on the Fluorescence Emission Spectra and Lifetimes of the Photosynthetic Components of Cyanobacteria. Biophysical Journal, 63(6), 1613-1622.

Fujimori, E. (1989). Cross-Linking and Fluorescence Changes of Collagen by Glycation and Oxidation. Biochimica Et Biophysica Acta, 998(2), 105-110.

Fujimoto, D., Akiba, K. Y., \& Nakamura, N. (1977). Isolation and Characterization of A Fluorescent Material in Bovine Achilles-Tendon Collagen. Biochemical and Biophysical Research Communications, 76(4), 1124-1129.

Gringer, N., Dang, T. T., Orlien, V., Olsen, K., Boknaes, N., \& Jessen, F. (2018). A Quantitative Method to Measure and Evaluate the Peelability of Shrimps (Pandalus Borealis). Lwt-Food Science and Technology, 94, 20-24.

Hassoun, A., \& Karoui, R. (2017). Quality Evaluation of Fish and Other Seafood by Traditional and Nondestructive Instrumental Methods: Advantages and Limitations. Critical Reviews in Food Science and Nutrition, 57(9), 1976-1998.

He, H., Adams, R. M., Farkas, D. F., \& Morrissey, M. T. (2002). Use of High-Pressure Processing for Oyster Shucking and Shelf-Life Extension. Journal of Food Science, 67(2), 640-645.

Hejazi, M., Behzad, T., Heidarian, P., \& Nasri-Nasrabadi, B. (2018). A Study of the Effects of Acid, Plasticizer, Cross-Linker, and Extracted Chitin Nanofibers on the Properties of Chitosan Biofilm. Composites Part a-Applied Science and Manufacturing, 109, 221-231.

Herrero, A. M. (2008). Raman Spectroscopy for Monitoring Protein Structure in Muscle Food Systems. Critical Reviews in Food Science and Nutrition, 48(6), 512-523. 
544 Heu, M. S., Kim, J. S., \& Shahidi, F. (2003). Components and Nutritional Quality of Shrimp Processing by-Products. Food Chemistry, 82(2), 235-242.

Hsu, K. C., Hwang, J. S., Chi, H. Y., \& Lai, K. M. (2010). Effect of Different High Pressure Treatments on Shucking, Biochemical, Physical and Sensory Characteristics of Oysters to Elaborate a Traditional Taiwanese Oyster Omelette. Journal of the Science of Food and Agriculture, 90(3), $530-535$. Treatment of Foods. Trends in Food Science \& Technology, 55, 84-97.

Jiang, L., Wang, Z., Li, Y., Meng, X., Sui, X., Qi, B., \& Zhou, L. (2015). Relationship between Surface Hydrophobicity and Structure of Soy Protein Isolate Subjected to Different Ionic Strength. International Journal of Food Properties, 18(5), 1059-1074.

Karoui, R., \& Blecker, C. (2011). Fluorescence Spectroscopy Measurement for Quality Assessment of Food Systems - A Review. Food and Bioprocess Technology, 4(3), 364-386.

Kopp, J., Bonnet, M., \& Renou, J. P. (1990). Effect of Collagen Crosslinking on Collagen-Water Interactions (A Dsc Investigation). Matrix, 9(6), 443-450.

Lascorz, D., Torella, E., Lyng, J. G., \& Arroyo, C. (2016). The Potential of Ohmic Heating as an Alternative to Steam for Heat Processing Shrimps. Innovative Food Science \& Emerging Technologies, 37, 329-335.

LiChan, E. C. Y. (1996). The Applications of Raman Spectroscopy in Food Science. Trends in Food Science \& Technology, 7(11), 361-370.

Mesias, M., Wagner, M., George, S., \& Morales, F. J. (2016). Impact of Conventional Sterilization and Ohmic Heating on the Amino Acid Profile in Vegetable Baby Foods. Innovative Food Science \& Emerging Technologies, 34, 24-28. 
568 Nan, J., Zou, M. L., Wang, H. B., Xu, C. Z., Zhang, J. T., Wei, B. M., He, L., \& Xu, Y. L. (2018). Effect of Ultra-High Pressure on Molecular Structure and Properties of Bullfrog Skin Collagen. International Journal of Biological Macromolecules, 111, 200-207.

571 Ngarize, S., Herman, H., Adams, A., \& Howell, N. (2004). Comparison of Changes in the Secondary Structure of Unheated, Heated, and High-Pressure-Treated Ss-Lactoglobulin and Ovalbumin Proteins Using Fourier Transform Raman Spectroscopy and Self-Deconvolution. Journal of Agricultural and Food Chemistry, 52(21), 6470-6477.

Nonaka, M., Lichan, E., \& Nakai, S. (1993). Raman-Spectroscopic Study of Thermally-Induced Gelation of Whey Proteins. Journal of Agricultural and Food Chemistry, 41(8), 1176-1181.

Ong, L. K., Danujatmiko, Z., Aylianawati, \& Sudaryanto, Y. (2014). The Prospect of Shrimp Shell Waste as Raw Material in the Gelatin Production (Vol. 9).

Pedersen, S. J., Feyissa, A. H., Kavli, S. T. B., \& Frosch, S. (2016). An Investigation on the Application of Ohmic Heating of Cold Water Shrimp and Brine Mixtures. Journal of Food Engineering, 179, $28-35$

Potekhin, S. A., Senin, A. A., Abdurakhmanov, N. N., \& Tiktopulo, E. I. (2009). High Pressure Stabilization of Collagen Structure. Biochimica Et Biophysica Acta-Proteins and Proteomics, 1794(8), 1151-1158.

Rahman, M. A., \& Halfar, J. (2014). First Evidence of Chitin in Calcified Coralline Algae: New Insights into the Calcification Process of Clathromorphum Compactum. Scientific Reports, 4, 6162.

Rau, J. V., Fosca, M., Graziani, V., Taffon, C., Rocchia, M., Caricato, M., Pozzilli, P., Muda, A. O., \& Crescenzi, A. (2017). Proof-of-Concept Raman Spectroscopy Study Aimed to Differentiate Thyroid Follicular Patterned Lesions. Scientific Reports, 7. 
590 Rodde, R. H., Einbu, A., \& Varum, K. M. (2008). A Seasonal Study of the Chemical Composition and Chitin Quality of Shrimp Shells Obtained from Northern Shrimp (Pandalus Borealis). 592 Carbohydrate Polymers, 71(3), 388-393.

Rødde, R. H., Einbu, A., \& Vårum, K. M. (2008). A Seasonal Study of the Chemical Composition and 594 Chitin Quality of Shrimp Shells Obtained from Northern Shrimp (Pandalus Borealis). Carbohydrate Polymers, 71(3), 388-393.

Raabe, D., Romano, P., Sachs, C., Fabritius, H., Al-Sawalmih, A., Yi, S., Servos, G., \& Hartwig, H. G. (2006). Microstructure and Crystallographic Texture of the Chitin-Protein Network in the Biological Composite Material of the Exoskeleton of the Lobster Homarus Americanus. Materials Science and Engineering a-Structural Materials Properties Microstructure and Processing, 421(1-2), 143-153.

Schubring, R. (2005). Characterizing Protein Changes Caused by Application of High Hydrostatic Pressure on Muscle Food by Means of Dsc. Journal of Thermal Analysis and Calorimetry, 82(1), 229-237.

Schubring, R. (2009). Comparative Study of Dsc Pattern, Colour and Texture of Shrimps During Heating. Journal of Thermal Analysis and Calorimetry, 95(3), 749.

Sengun, I. Y., Turp, G. Y., Icier, F., Kendirci, P., \& Kor, G. (2014). Effects of Ohmic Heating for PreCooking of Meatballs on Some Quality and Safety Attributes. Lwt-Food Science and Technology, $55(1), 232-239$.

Sriket, P., Benjakul, S., Visessanguan, W., \& Kijroongrojana, K. (2007). Comparative Studies on Chemical Composition and Thermal Properties of Black Tiger Shrimp (Penaeus Monodon) and White Shrimp (Penaeus Vannamei) Meats. Food Chemistry, 103(4), 1199-1207.

Swatland, H. J., Nielsen, T., \& Andersen, J. R. (1995). Correlations of Mature Beef Palatability with Optical Probing of Raw Meat. Food Research International, 28(4), 403-416. 
614 Verhaeghe, T., Vlaemynck, G., De Block, J., Van Weyenberg, S., Braeckman, R., \& Hendrickx, M. 615 (2016). Kinetics of Heat Induced Muscle Protein Denaturation of Brown Shrimp (Crangon 616 Crangon). Journal of Food Engineering, 191, 88-94.

617 Vivian, J. T., \& Callis, P. R. (2001). Mechanisms of Tryptophan Fluorescence Shifts in Proteins. 618 Biophysical Journal, 80(5), 2093-2109.

619 Voisin, E. A. (2001). U.S Patent No. 6,217,435 B1. Washington, DC: U.S. Patent and Trademark Office. 620 Wasswa, J., Tang, R., \& Gu, X. H. (2007). Utilization of Fish Processing by-Products in the Gelatin $621 \quad$ Industry. Food Reviews International, 23(2), 159-174.

622 Wongsa-Ngasri, P., \& Sastry, S. K. (2015). Effect of Ohmic Heating on Tomato Peeling. Lwt-Food 623 Science and Technology, 61(2), 269-274.

624 Wongsa-Ngasri, P., \& Sastry, S. K. (2016a). Tomato Peeling by Ohmic Heating with Lye-Salt 625 Combinations: Effects of Operational Parameters on Peeling Time and Skin Diffusivity. Journal 626 of Food Engineering, 186, 10-16.

Zell, M., Lyng, J. G., Cronin, D. A., \& Morgan, D. J. (2010). Ohmic Cooking of Whole Turkey Meat 635 Effect of Rapid Ohmic Heating on Selected Product Parameters. Food Chemistry, 120(3), 724636 729. 
637 Table 1. Effect of ohmic heating on shrimp peelability

\begin{tabular}{|c|c|c|c|c|c|}
\hline \multirow{2}{*}{$\begin{array}{l}\text { Salt } \\
(\%)\end{array}$} & \multirow{2}{*}{$\begin{array}{l}\text { Voltage } \\
\text { (V) }\end{array}$} & \multirow{2}{*}{$\begin{array}{l}\text { Temperature } \\
\left({ }^{\circ} \mathrm{C}\right)\end{array}$} & \multirow{2}{*}{$\begin{array}{l}\text { Peeling Work } \\
(\mathrm{mJ} / \mathrm{g})\end{array}$} & \multicolumn{2}{|l|}{ Three-way ANOVA } \\
\hline & & & & Effect term & $p$ value \\
\hline 0 & 0 & 0 & $4.2 \pm 2.1^{\mathrm{de}}$ & Salt & $<0.0001$ \\
\hline 2 & 92 & 30 & $4.7 \pm 1.9^{\text {de }}$ & Voltage & $<0.0001$ \\
\hline 2 & 92 & 35 & $4.0 \pm 1.9^{\mathrm{de}}$ & Temperature & $<0.0001$ \\
\hline 2 & 92 & 40 & $4.4 \pm 1.4^{\mathrm{de}}$ & Salt*Voltage & 0.0096 \\
\hline 2 & 92 & 50 & $5.5 \pm 2.0^{\text {bcde }}$ & Salt*Temperature & 0.0005 \\
\hline 2 & 138 & 30 & $4.0 \pm 1.2^{\mathrm{de}}$ & Voltage*Temperature & 0.1649 \\
\hline 2 & 138 & 35 & $5.4 \pm 3.0^{\text {bcde }}$ & Salt*Voltage*Temperature & 0.1857 \\
\hline 2 & 138 & 40 & $4.3 \pm 1.5^{\mathrm{de}}$ & Model & $<0.0001$ \\
\hline 2 & 138 & 50 & $6.2 \pm 2.0^{\mathrm{bcd}}$ & & \\
\hline 2 & 138 & 60 & $6.1 \pm 2.0^{\mathrm{bcd}}$ & & \\
\hline 2 & 184 & 30 & $5.2 \pm 2.5^{\text {bcde }}$ & & \\
\hline 2 & 184 & 35 & $5.0 \pm 2.4^{\text {cde }}$ & & \\
\hline 2 & 184 & 40 & $4.3 \pm 1.2^{\mathrm{de}}$ & & \\
\hline 2 & 184 & 50 & $5.7 \pm 1.8^{\text {bcde }}$ & & \\
\hline 2 & 184 & 60 & $5.5 \pm 1.4^{\text {bcde }}$ & & \\
\hline 10 & 92 & 30 & $3.5 \pm 1.2^{\mathrm{e}}$ & & \\
\hline 10 & 92 & 35 & $5.5 \pm 1.4^{\text {bcde }}$ & & \\
\hline 10 & 92 & 40 & $5.4 \pm 2.0^{\text {bcde }}$ & & \\
\hline 10 & 92 & 50 & $6.2 \pm 2.1^{\mathrm{bcd}}$ & & \\
\hline 10 & 138 & 20 & $4.4 \pm 1.8^{\mathrm{de}}$ & & \\
\hline 10 & 138 & 30 & $5.6 \pm 2.3^{\text {bcde }}$ & & \\
\hline 10 & 138 & 35 & $6.2 \pm 2.3^{b c d}$ & & \\
\hline 10 & 138 & 40 & $7.2 \pm 2.5^{\mathrm{bc}}$ & & \\
\hline 10 & 138 & 50 & $9.8 \pm 1.9^{\mathrm{a}}$ & & \\
\hline 10 & 138 & 60 & $9.9 \pm 2.5^{\mathrm{a}}$ & & \\
\hline 10 & 184 & 20 & $4.6 \pm 1.7^{\mathrm{de}}$ & & \\
\hline 10 & 184 & 30 & $5.6 \pm 2.0^{\text {bcde }}$ & & \\
\hline 10 & 184 & 35 & $5.8 \pm 2.6^{\text {bcde }}$ & & \\
\hline 10 & 184 & 40 & $6.1 \pm 2.1^{\mathrm{bcd}}$ & & \\
\hline 10 & 184 & 50 & $7.5 \pm 3.1^{\mathrm{b}}$ & & \\
\hline
\end{tabular}

638 Values in the same column with different letters are significantly different at $p<0.05$, based on Student-

639 Newman-Keuls test. 

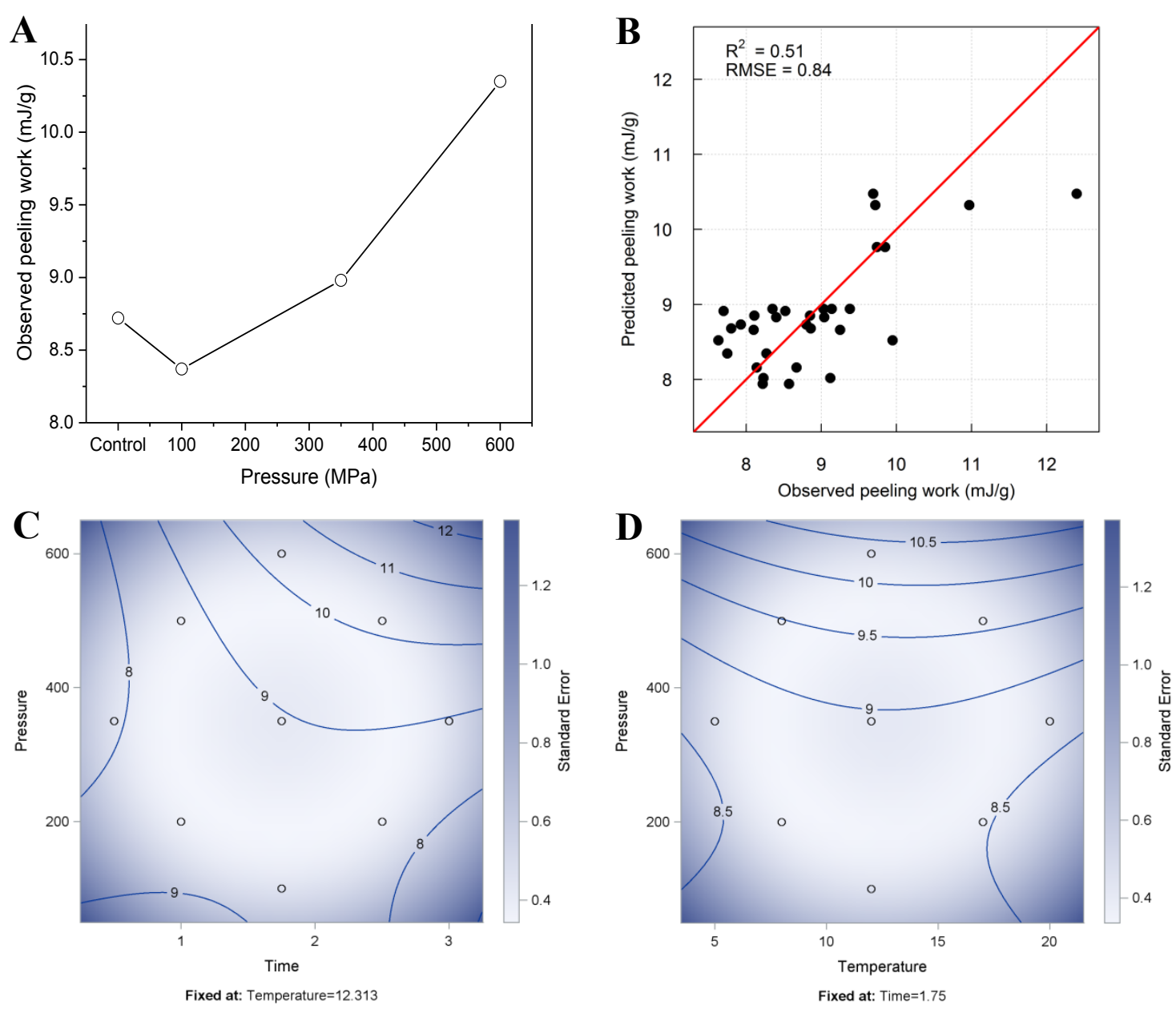

640 Figure 1. High pressure effect on shrimp peelability. (A) individual effect of pressure level on peeling 641 work when fixing time at $1.75 \mathrm{~min}$ and temperature at $12.5^{\circ} \mathrm{C}$, (B) observed vs. predicted values for 642 peeling work obtained by response surface method, (C-D) contour plots of paired interaction of HP 643 conditions on peeling work. 

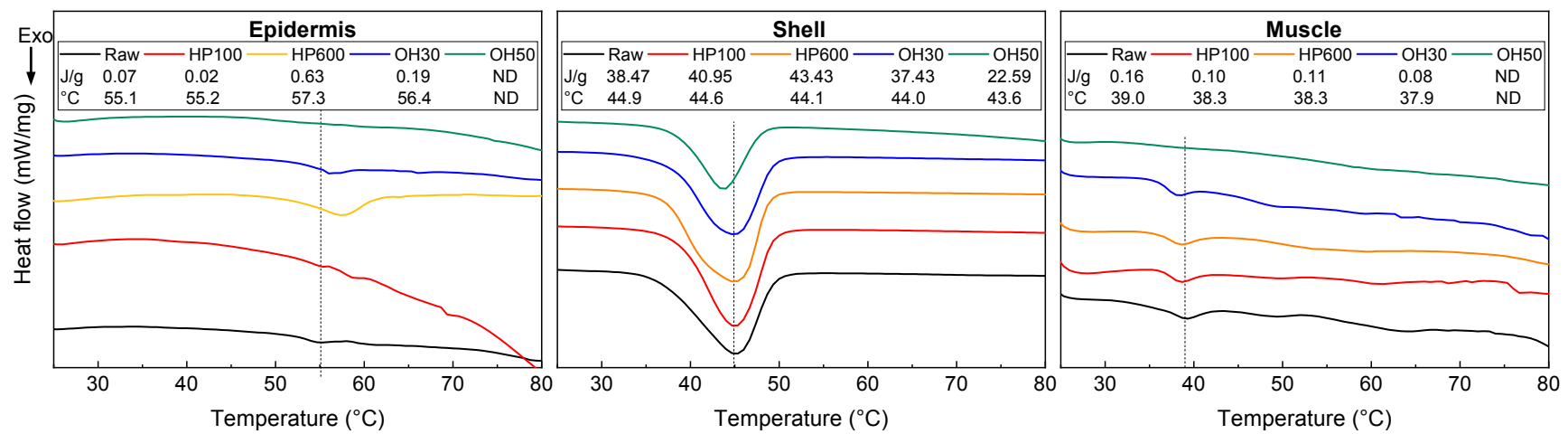

644 Figure 2. DSC thermogram of parts of shrimp under different conditions of high pressure and ohmic 645 heating processing. Raw, control shrimp; HP100, high pressure at $100 \mathrm{MPa}$; HP600, high pressure at 600 $646 \mathrm{MPa}$; $\mathrm{OH} 30$, ohmic heating at $30^{\circ} \mathrm{C}$; and $\mathrm{OH} 50$, ohmic heating at $50^{\circ} \mathrm{C}$. Vertical dash line marks the 647 transition temperature of raw shrimp. $\mathrm{ND}=$ not detected, $\mathrm{J} / \mathrm{g}=$ unit of enthalpy change $(\Delta \mathrm{H}),{ }^{\circ} \mathrm{C}=\mathrm{unit}$ 648 of transition temperature of the peak marked with the dash line. 

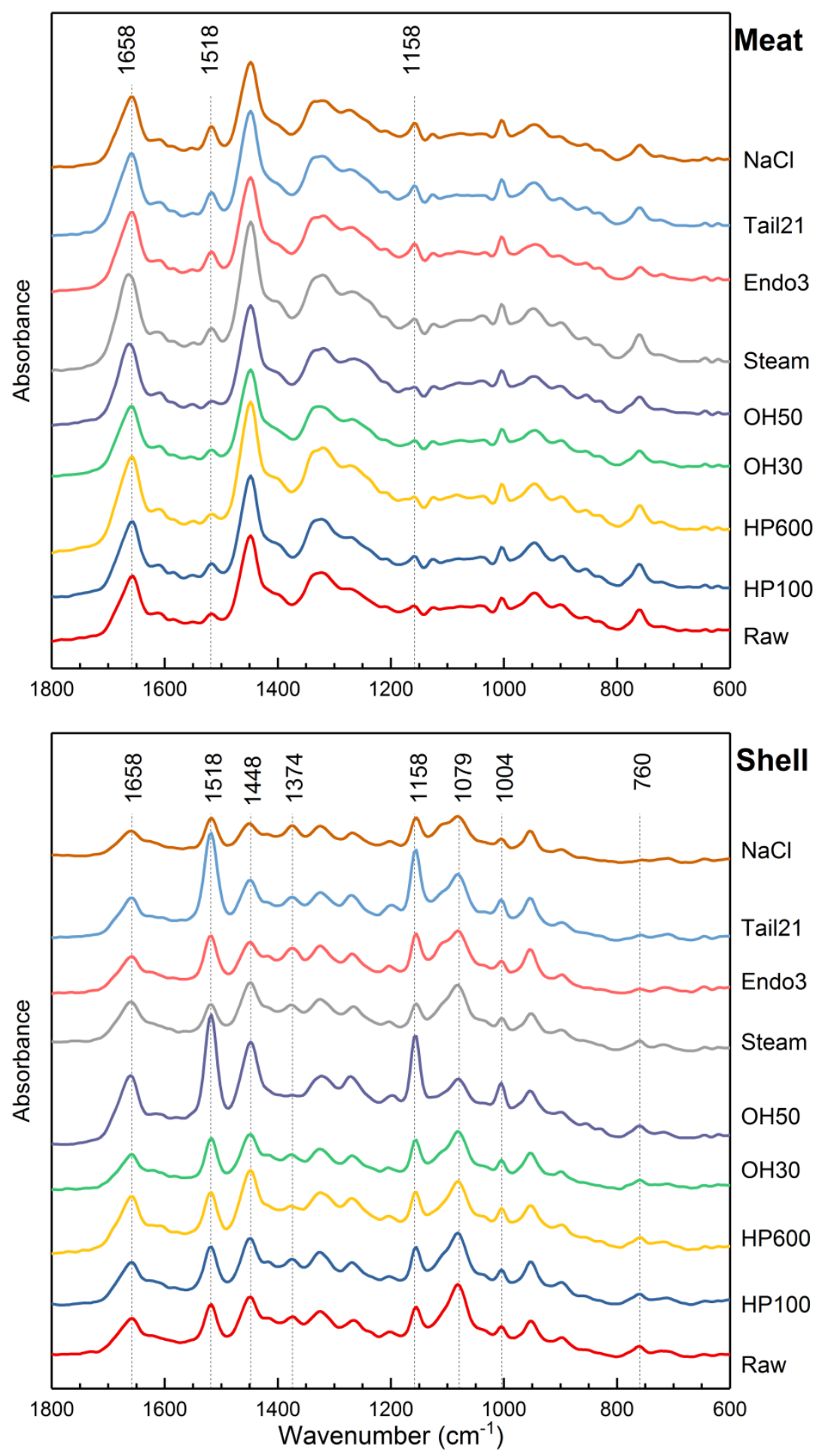

649 Figure 3. Raman spectra of meat and shell subjected to different treatments. Each spectrum is an average 650 of three spectra from three shrimp. Peaks with an arrow and numeric label are peaks modified by one of 651 the treatments in terms of intensity and visibility. 

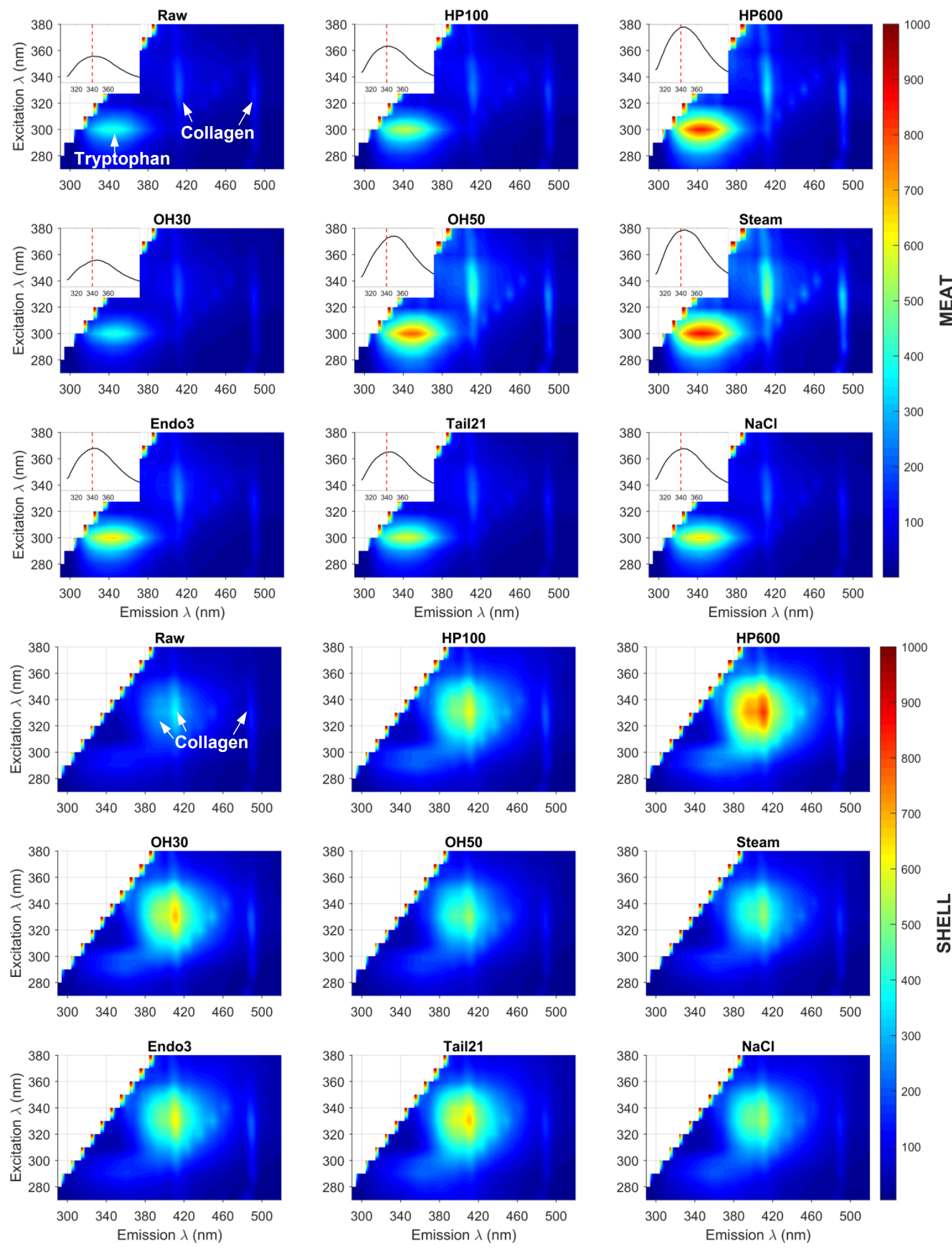

653 Figure 4. Fluorescence landscapes of shrimp meat and shell subjected to different treatments. Inset 654 figures in meat set represent emission fluorescence spectra of tryptophan at 300-nm excitation, and the red dash line positions at 340-nm emission. Color bars on the right indicates the fluorescence intensity. 


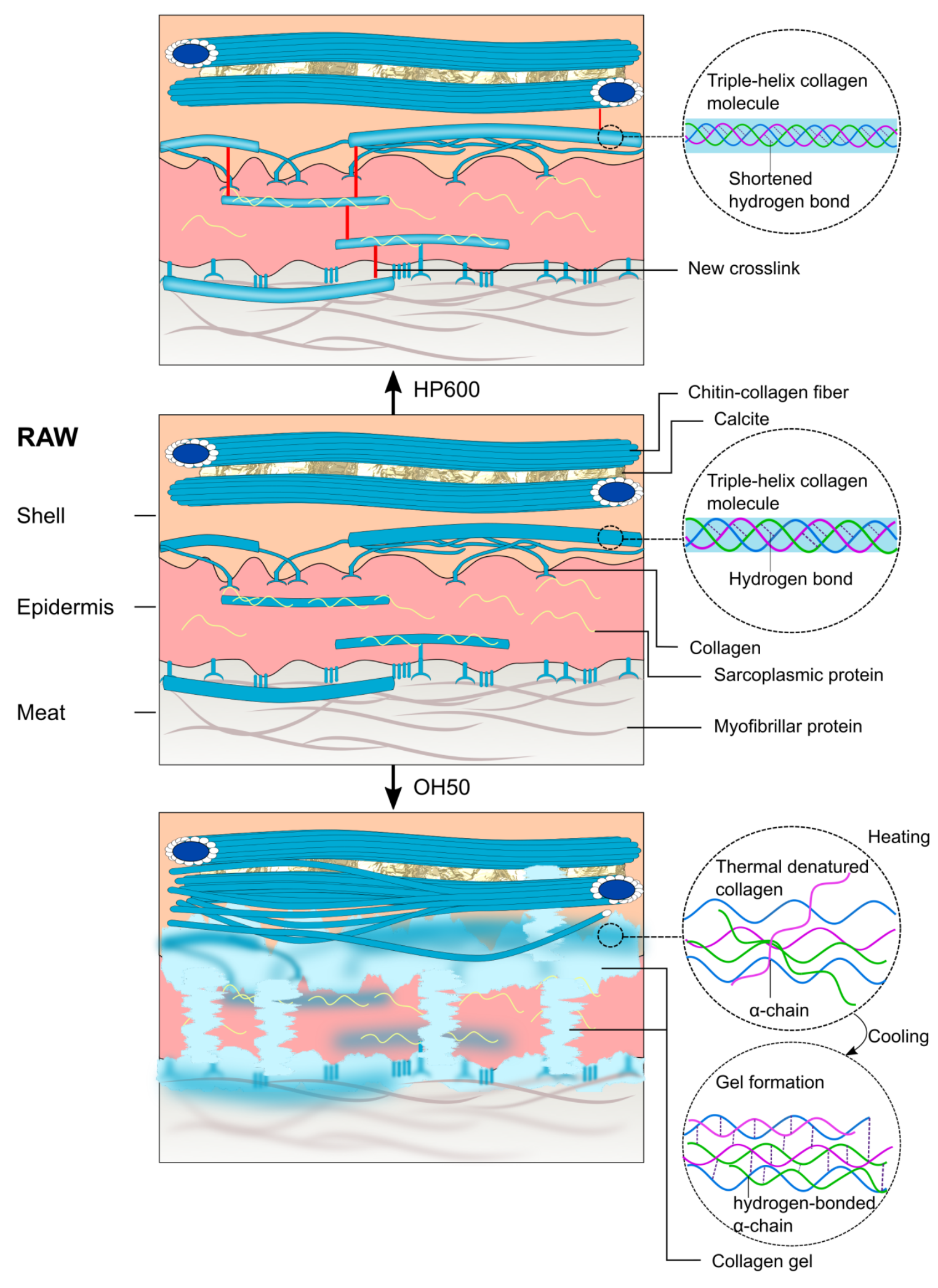

656 Figure 5. Proposed mechanism of shell tightening of shrimp caused by extreme conditions of high 657 pressure $(600 \mathrm{MPa})$ and ohmic heating $\left(50^{\circ} \mathrm{C}\right)$. 